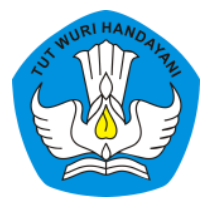

Page: 557-580

\title{
METODE CONSULTANT SOCIAL SCIENCE DALAM UPAYA MENINGKATKAN KEMAMPUAN KOLABORASI DAN KOMUNIKASI SISWA
}

\section{Lestari Kurniawati}

Sekolah Menengah Pertama Negeri 1 Rangkasbitung

Contributor Email: lestari.kurniawati@rocketmail.com

Published: Jul 30, 2020

Article Url: https:/ /ojsdikdas.kemdikbud.go.id/index.php/didaktika/article/view/146

\begin{abstract}
The purpose of the study was to improve students' collaboration and communication skills using the Social Sciences Consultant method in class IX.D SMPN 1 Rangkasbitung. Research using quantitative descriptive methods, begins by conducting data collection, data analysis, making conclusions and description of data based on the conditions as they are. The results showed the Social Sciences Consultant's method could improve aspects of Collaboration, sessions I and II, namely: 1). The Hasanudin group numbered $15 \%$ which was seen from the increase; 2). Imam Bonjol Group is $10 \%$ 3). Teuku Umar group is 5\%; 4). Cut NyakDien's group is $10 \%$; 5). Kartini group is 5\%; and 6). The Pattimura group is $20 \%$. Communication Aspects 1). Hasanudin group is 10\%; 2). Imam Bonjol's group is $5 \%$; 3). Teuku Umar group is 5\%; 4). Cut NyakDien's group is 10\%; 5). Kartini group is $10 \%$; and 6). Pattimura group is $10 \%$.
\end{abstract}

Keywords: Consultant Social Science Method, Collaboration, Communication 


\begin{abstract}
Abstrak
Tujuan penelitian untuk meningkatkan kemampuan kolaborasi dan komunikasi siswa menggunakan metode Consultant Social Science pada kelas IX.D SMPN 1 Rangkasbitung. Penelitian menggunakan metode deskriptif kuantitatif, diawali dengan melakukan pengumpulan data, analisis data, membuat kesimpulan dan deskripsi data berdasarkan kondisi yang apa adanya. Hasil penelitian menunjukkan metode Consultant Social Science dapat meningkatkan aspek kerjasama, sesi I dan II, yaitu: 1). Kelompok Hasanudin sejumlah 15\% yang dilihat dari kenaikan; 2). Kelompok Imam Bonjol 10\% 3). Kelompok Teuku Umar sejumlah 5\%; 4). Kelompok Cut Nyak Dien sejumlah 10\%;5). Kelompok Kartini sejumlah 5\%; dan 6). Kelompok Pattimura sejumlah 20\%. Aspek komunikasi, yaitu 1). Kelompok Hasanudin sejumlah 10\%; 2). Kelompok Imam Bonjol sejumlah 5\%; 3). Kelompok Teuku Umar sejumlah 5\%; 4). Kelompok Cut Nyak Dien sejumlah 10\%; 5). Kelompok Kartini sejumlah 10\%; dan 6). Kelompok Pattimura sejumlah $10 \%$.
\end{abstract}

Kata Kunci: Metode Consultant Social Science, kolaborasi, Komunikasi

\title{
A. Pendahuluan
}

Dinamika pendidikan Indonesia mulai mengalami disrupsi di Era Revolusi Industri 4.0. Hadirnya ruang belajar online, penggunaanInternet of Things, bermuara pada akses informasi dan pengetahuan yang sangat memungkinkan siswa beralih pada kepraktisan dalam belajar. Namun di sisi lain, meluapnya arus informasi jika tidak dibarengi dengan pemikiran kritis akan memicu miskomunikasi dan kurangnya kolaborasi dalam kehidupan kelas. Contoh sederhana adalah munculnya "kultus individu" dalam kegiatan pembelajaran yang menuntut adanya kerjasama.

Aspek kolaborasi dan komunikasi merupakan salah satu bagian dari 4 (empat) karakater pembelajaran abad 21, yaitu Critical Thinking and Problem Solving, dan Creativity and Inovation. Permasalahan yang paling sering penulis temui dalam kegiatan diskusi siswa di kelas IX.D SMPN 1 Rangkasbitung, terkait kecakapan abad 21adalah adanya kelemahan dalam berkolaborasi dan komunikasi dalam setiap kelompok diskusi. Hasil kuesioner yang penulis sebar, diperoleh data bahwa 19\% mereka menganggap kerja sama dapat berjalan jika semua anggota mau menuangkan ide/gagasan, 16,6\% semua pihak harus aktif berbicara, $12 \%$ 
harus bisa menghargai perbedaan pendapat, $12 \%$ menguasai materi, $12 \%$ bertanggung jawab, dan Memanfaatkan waktu dengan baik serta kreatif $7,4 \%$ serta sisanya masing-masing $7 \%$ adalah berani mengeluarkan pendapat, tidak bermalas-malasan dan mau bekerja sama dengan baik.

Faktanya yang terjadi di kelas IX.D adalah kesulitan mengeluarkan pendapat sebanyak $20 \%$, jika terjadi pembicaraan diskusi hanya dikuasai dua atau tiga orang saja yang memiliki keterampilan berbicara $19 \%$, pendapat kita diabaikan $12 \%$, kurangnya kepercayaan diri dalam berpendapat $19 \%$, tidak mau bekerjasama karena merasa bisa menangani pekerjaan teman $4,8 \%$, tidak memahami materi dengan baik 10,3\%, egois 7,9 \%, dan diskusi berantakan sebanyak 7\%. Hasilnya, kegiatan kerja kelompok menjadi kontraproduktif dan berimbas pada rendahnya kualitas hasil pembelajaran siswa.

Menghadapi fenomena tersebut, penulis mencoba mengubah posisi dalam kelompok, yakni menawarkan metode baru yang bertujuan meningkatkan kualitas pembelajaran berkelompok dengan Consultant Social Science (CSS) pada mata pelajaran IPS. Metode CSSpenulis menjadikan siswa yang kurang aktif dalam diskusi dan selama ini secara kognitif dianggap biasa-biasa saja oleh rekan sejawatnya, justru diberi kesempatan untuk menjadi konsultan pembelajaran. Hal itu terus dilakukan berulang dan bergiliran setiap dua kali pertemuan dalam sepekan. Siswa yang pasif dalam kelompok diberikan kebebasan dalam mengeksplor pengetahuannya masing-masing dan dituntut untuk mensharing pengetahuannya dalam kelompok. Sharing knowledge antarsiswa diyakini menambah pengetahuan dan pengalaman siswa, tetapi juga menambah kepercayaan diri serta rasa tanggung jawab siswa yang selama ini terabaikan dalam kelompok diskusi. Selanjutnya dengan siswa dilatih untuk berkomunikasi dan mengeluarkan gagasan/ide, dapat melatih analisis dan pemecahan masalah. Selain itu, dominasi tradisional guru di kelas, menjadi berkurang sehingga peran guru beralih menjadi fasilitator dan evaluator.

Metode pembelajaran Consultant Social Science ada beberapa hal yang melandasi, antara lain pembelajaran cooperative. Pembelajaran 
cooperative didasarkan atas konsep pemikiran dari Maslow dan Bruner. Pendapat yang diutarakan oleh Bruner yang isinya menekankan pada pemenuhan kebutuhan secara berkelompok dan mereka saling berinteraksi satu sama lain dalam mencapainya(Silberman, 2010, hal. 9). Aktivitas belajar kolaboratif mengarah pada pembelajaran aktif. Pembelajaran aktif merangsang siswa untuk berinteraksi dan mengerjakan tugas secara berkelompok maupun diskusi. Pembelajaran berkelompok juga mengarah pada bentuk paradigma pembelajaran konstruktivis sosial. Pembelajaran kontruktivis menekankan pada pembelajaran dengan secara berkelompok dan membangun pengetahuan secara berkelompok pula. (Santrock, 2010, hal. 390)

Metode CSS sejalan dengan problem-posing education atau siswa dihadapkan pada berbagai permasalahan (Freire, 2011, hal. xxi),menekankan bahwa siswa dan guru dijadikan dalam kelompok yang sama bukan sebagai subjek-objek. Siswa bersifat egaliter, yaitu tidak melihat siswa sebagai objek yang dibeda-bedakan berdasarkan tingkatan kecerdasan dan kedudukan siswa sama. Siswa juga diberikan kebebasan dalam membangun pola pikirnya sendiri dan menganalisis setiap permasalahan/materi yang diberikan oleh guru, dan guru menjadi fasilitator bagi siswa yang kesulitan membangun pola pikir dan sikap kritis.

Anantyarta, dkk menekankan 5 aspek pembentuk kolaborasi siswa dalam proses pembelajaran, antara lain: Productive and Efficient, Appreciation Opinion, Contribution, Compromise and Flexible, dan Responsibility (Anantyarta \& Sari, 2017, hal. 37). Sedangkan aspek komunikasiada 5 (lima) dalam mengembangkan komunikasi yang efektif dalam dunia pendidikan di era sekarang, antara lain adalah: Clarity/ Kejelasan, bahasa yang sederhana dan digunakan harus berisi informasi yang benar; Accuracy/Ketepatan, penggunaan bahasa agar mudah dipahami; Context/ Konteks, bahasa yang digunakan harus sesuai dengan konteks, kondisi dan lingkungan yang menjadi bahan pembicaraan; Plot/alur, bahasa dan informasi yang digunakan harus disusun secara 
berurutan dan sistematis agar informasi mudah dipahami; dan Culture/budaya, penggunaan bahasa harus menggunakan etika dan tata krama sesuai dengan budaya masyarakat (Lestari. G, 2015, hal. 45).

Perkembangan informasi yang pesat, juga menandai revolusi komunikasi yang cepat pula. saat ini, komunikasi menjadi sarana yang paling digemari oleh masyarakat, informasi menjadi cepat dan mudah diterima, keterbukaan informasi dan akses yang cepat membuat masyarakat mampu mengolah informasi dengan baik (Khasali, 2018, hal. 420).

Komunikasi efektif berperan penting yang menunjang proses belajar mengajar. Komunikasi yang efektif dalam pembelajaran mencakup antara lain penyajian yang jelas, kelancaran berbicara, interpretasi gagasan abstrak dengan menggunakan contoh-contoh, kemampuan berbicara yang baik (nada, intonasi dan ekspesi) dan kemampuan untuk mendengar(Uno \& Mohamad, 2011, hal. 180). Komunikasi yang efektif wajib dibangun oleh individu-individu yang terlibat dalam proses belajar (siswa/pelajar dan guru/tutor). Dengan terciptanya komunikasi yang efektif, maka penunjang proses pembelajaran akan menjadi lebih tercapai.

Penulis meyakini dengan metode CSS menjadi solusi sekaligus akan merubah paradigma pembelajaran, bahwa sejatinya pembelajar sejati adalah yang mau belajar, siswa belajar dengan siswa lainnya, siswa belajar dari guru, guru juga belajar dari siswa. Penggunaanaplikasi metode CSS memiliki tujuan yang mendasar yaitu peningkatan kualitas belajar dan pembelajar siswa, namun yang menjadi acuan pada kualitas juga dipengaruhi oleh aspek kolaborasi dan komunikasi. Tujuan karya inovasi ilmiah antara lain:

1. Metode Consultant Social Sciencedapat meningkatkan kemampuan kolaborasi siswa.

2. Metode Consultant Social Science dapat meningkatkan kemampuan komunikasi siswa.

Adapun manfaat secara general karya inovasi ilmiah ini, bahwa guru harus berani membuat suatu terobosan yang kritis terhadap perkembangan siswa, agar peningkatan kualitas belajar dan pembelajaran siswa sebagai tujuan mendasarnya diupayakan maksimal. 
Secara spesifik, manfaat yang bisa didapatkan adalah pemberian wawasan dan pengetahuan baru dalam pengembangan metode belajar yang anti mainstream. Mencoba mengembangkan metode belajar yang tidak biasa, namun tidak melupakan aspek kualitas.

\section{B. Metode}

Desain penelitian menggunakan Penelitian Tindakan Kelas melalui dua siklus. Penelitian Tindakan kelas atau Classroom Action Research dipilih karena tujuan penelitian adalah untuk memperbaiki hasil pembelajaran di kelas, diikuti penemuan yang sistematis, proses reflektif, partisipatif dan ditentukan oleh guru di kelas bersama kolaborator (Kamber, 2000).Penelitian di lakukan di SMPN 1 Rangkasbitung dengan jumlah subyek penelitian yakni sebanyak 42 siswa di kelas IX.D.

Instrument Pengumpulan data dilakukan dengan menggunakan teknik pengumpulan data kuantitatif yang meliputi: survei analisis perilaku siswa di kelas, sebaran kuesioner, dan jurnal penilaian sikap. Penulismenginginkankerjakelompok yang baiksetelah terbentuk secara heterogen. Adanya kesenjangan antara siswa yang terkenal pintar dengan siswa yang memiliki kemampuan biasa, menjadi tidak sehat bagi perkembangan kognitif dan psikologisnya. Solusi diskusi dan pemberian tugas project yang terhambat, memerlukan solusi jangka panjang agar kejadian yang sama tidak berulang. Maka, pola perilaku perubahan mindset anggota kelompok harus diubah. Langkah pertama yang penulis lakukan dengan memantau perkembangan kelompok dan menampung banyak keluhan siswa, mendiagnosa permasalahan yang terjadi saat pengerjaan project. Langkah kedua, transfer ilmu antar anggota kelompok, sehingga kelompok menjadi lebih dinamis dan efektif dalam mengerjakan tugasnya. Kolaborasi yang terabaikan menyebabkan tugas yang dikerjakan menjadi kurang efektif dan kontra produktif.

Langkah Ketiga, penulis memilih seorang consultant (baca: konsultan) dari masing-masing kelompok.Konsultan, adalah seorang siswa yang selama ini dianggap masih "kurang" dalam pembelajaran, menekankan agar mau mempelajari materi lebih dibandingkan siswa 
lainnya. Pemilihan CSS ini didasarkan pada konsep kesetaraan. Siswa yang "kurang" secara kognitif dalam pemahaman materi diberikan kesempatan untuk menjadi CSS, dan memiliki peran dalam setiap kelompoknya masing-masing.

Diharapkan dengan pemilihan CSS, siswa yang terpilih termotivasi dalam pembelajaran dan mampu berkomunikasi serta berkolaborasi dengan siswa anggota kelompok lainnya. Siswa yang dipilih sebagai CSS diberikan pengertian akan pentingnya arti sharing ilmu terhadap temantemannya, agar pemahaman keilmuan menjadi merata. Begitu pula bagi seluruh siswa diberikan kesempatan untuk bertanya sebebas mungkin kepada siswa yang diberi tugas sebagai CSS. Adapun syarat-syarat pemilihan CSS siswa yang "kurang" dalam bentuk pemahaman pembelajaran IPS, "kurang" berinteraksi dalam setiap kelompok, dan "kurang" berkolaborasi dalam pengerjaan tugas/proyek kelompok.

Langkah-langkah Metode CSS meliputi tahapanpra, proses, dan pasca kegiatan. Prakegiatan meliputi pemilihan CSS sesuai dengan syarat dan kriteria yang sudah ditentukan dan pemberian pemahaman kepada siswa yang terpilih sebagai CSS untuk mempelajari lebih materi dibandingkan dengan siswa lainnya. Hal ini dilakukan secara reguler. Tahapan Proses Kegiatan yaitu pembentukan kelompok dan menyebar CSS yang terpilih, pemberian materi kepada seluruh kelompok, proses komunikasi dan kolaborasi antar kelompok dengan CSS, pemberian Tugas/Projek kepada seluruh kelompok, observasi kepada seluruh kelompok, dan penilaian melalui rubrik aspek Collaboration dan Communication pada setiap kelompok.Tahapan Pasca Kegiatan meliputi proses penilaian/uji kemampuan aspek kognitif bagi seluruh siswa, pengolahan penilaian aspek Collaboration, Communication dan kognitif siswa, dan reflektif kegiatan.

\section{Hasil dan Pembahasan}

Penelitian menunjukkan terjadinya peningkatan aktivitas dan hasil belajar siswa dengan menggunakan model pembelajaran kolaboratif (Lasidos, Pahala Arion dan Zulkifli Matondang, 2015). Penelitian ini 
menemukan siswa merasakan efektif, karena siswa/i yang pasif di kelas jadi berani bertanya $38,1 \%$ dan mulai berani mengemukakan pendapat terhadap siswa yang selama ini kesulitan mengomunikasikannya ke sesama yakni $23,8 \%$, siswa lain berpendapat sudah ada siswa yang pasif berusaha membuat orang yang konsultasi padanya paham dengan menggunakan media 30\%, dan dalam konsultan IPS ini siswa yang pasif dianjurkan menguasai materi dan punya wawasan luas $8 \%$. Penelitian lain menunjukkan terdapat perubahan sikap dari siswa/I pasif menjadi aktif dalam CSS karena adanya pergantian peran, semua siswa dituntut untuk berani mengemukakan pendapat disertai data sebanyak 57,1 \%. Meskipun, terkadang masih ada antara pertanyaan dan jawaban yang diberikan konsultan tidak memecahkan masalah (Auratu, 2018).

Dominasi di kelompok dalam sesi I dan II masih ditemukan sebanyak $28,57 \%$, sementara proses pergantian peran tiap pergantian topik, membantu siswa pasif berani tampil aktif sebesar $57,1 \%$ pada sesi I dan II, meskipun anggota yang pasif masih harus didorong dan dimotivasi sebanyak 14,3\%. Pada kuesioner no.3 ditanyakan apakah metode CSS bisa menjadi solusi? Hampir $71,42 \%$ menyatakan dapat menjadi solusi karena mulai beralihnya siswa yang aktif selama ini pada siswa yang tidak aktif, serta siswa dituntut untuk menguasai bahan diskusi. Sementara sebanyak 12 siswa masih menyatakan belum menjadi satu-satunya solusi karena $28,57 \%$ menyatakan masih ada siswa yang kurang memahami materi diskusi. Seringkali pertanyaan di lemparkan lagi ke rekan lainnya.

Presentase data yang menunjukkan adanya perubahan sikap dari siswa sebanyak $57,2 \%$ menyatakan siswa yang terlibat sudah aktif sementara sisanya $23,8 \%$ sudah aktif namun masih harus butuh motivasi lebih. Dengan metode CSS ini juga sebanyak 59,5\% siswa merasakan lebih mudah memahami materi karena yang menyampaikan adalah rekannya sendiri yang menggunakan bahasa lebih mudah dicerna, sementara 28,57\% masih menggunakan bahasa buku dan kurang kreatif dalam mencari solusi permasalahan, dan lainnya menganggap perlu banyak membaca bagi konsultan IPS sebanyak 11,9\%. 
Penggunaan angket/kuesioner oleh penulis dilengkapi dengan menyediakan rubrik penilaian berdasarkan aspek Collaboration dan Comunication, selanjutnya penulis juga mengukur kemampuan kognitif siswa dengan memberikan Ulangan Harian I sebagai pretest dan Ulangan Harian II sebagai postest. Dalam mengukur aspek Collaboration dan Comunication, penulis melihat dinamika setiap kelompok. Dinamika kelompok yang terjadi di setiap kelompok memiliki karakteristik masingmasing, dan inilah kelebihan dari metode CSS, ketika setiap konsultan IPS memberikan pemahaman yang lebih beragam ke anggota kelompoknya dan membuat dinamika kelompok menjadi lebih hidup. Dalam memaparkan hasil penelitian, penulis menggunakan tampilan excel dan grafik untuk memudahkan pembaca dalam melihat dan menganalisis hasil penelitian.

\section{Hasil}

\section{a. Aspek Collaboration}

Desain rubrik aspek collaborationdigambarkan pada Tabel 1.

Tabel 1. Desain Rubrik AspekCollaboration

\begin{tabular}{|c|c|c|c|c|c|c|}
\hline \multirow[b]{2}{*}{ SUB ASPEK } & \multicolumn{4}{|c|}{ Deskipii Skor } & \multirow{2}{*}{$\begin{array}{l}\text { Rent } \\
\text { ang } \\
\text { Skor } \\
\text { Skor }\end{array}$} & \multirow[b]{2}{*}{ Kriteria Skor } \\
\hline & 1 & 2 & 3 & 4 & & \\
\hline Productiox \& & $\begin{array}{l}\text { Kelompoksamasekalitidakmelakssiswaantug } \\
\text { sany adenganbaik dan tidak ada kejassama }\end{array}$ & 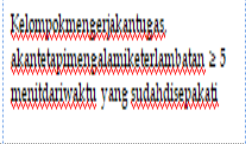 & 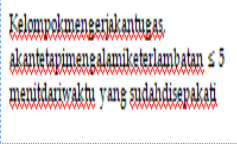 & 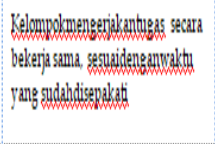 & 1.4 & 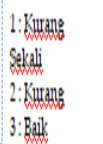 \\
\hline Apprciciabon & $\begin{array}{l}\text { Tidak menghlargea pendapat antar sesama } \\
\text { angogota kelonpok dan kelompok Lain }\end{array}$ & 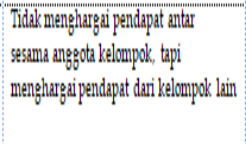 & 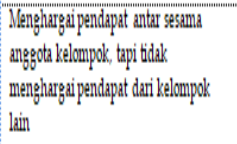 & $\begin{array}{l}\text { Menghargea pendapat antar sesama } \\
\text { angegota kelompok dan kelompok } \\
\text { Lain }\end{array}$ & 1.4 & 4:Barsokali \\
\hline Contivition & 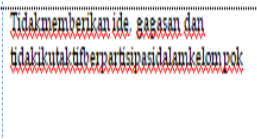 & 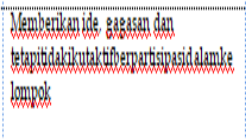 & 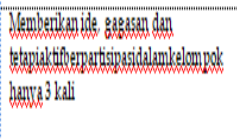 & 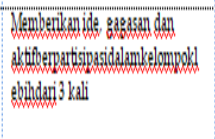 & $1 \cdot-4$ & $\begin{array}{l}\text { Kelompok akan } \\
\text { mendapatkanka } \\
\text { nuildi } \\
\text { sempuna bila }\end{array}$ \\
\hline Gomponicis 8 & $\begin{array}{l}\text { Tidak man bekkoupromi dan Aeksibel } \\
\text { dalam melaksiswoan tugas }\end{array}$ & $\begin{array}{l}\text { Mau berkompromi, tapi idadk Alekibel } \\
\text { dalam melakssiswan trigas }\end{array}$ & $\begin{array}{l}\text { Tidak maul betkompromi, tapi feksivel } \\
\text { dalam melalssiswaan tugas }\end{array}$ & $\begin{array}{l}\text { Mau berkompronid dar fekcibel } \\
\text { daldm melakssisvanan tugas }\end{array}$ & $1-4$ & $\begin{array}{l}\text { memperoleh } \\
\text { NILAI } \\
\text { SEMPURNA }\end{array}$ \\
\hline Respousbility & 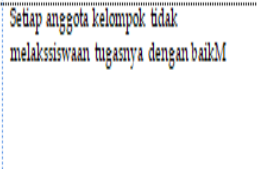 & 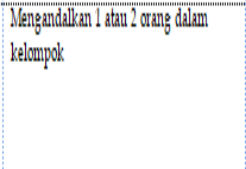 & $\begin{array}{l}\text { Setengahd dari total angogota kelompok' } \\
\text { suddh menijankan tugasury dengan } \\
\text { bailk }\end{array}$ & 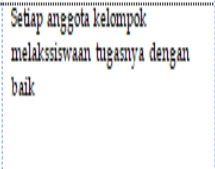 & $1-4$ & 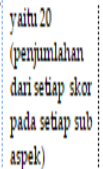 \\
\hline
\end{tabular}

Sumber: (Anantyarta \& Sari, 2017, hal. 37). 
Hasil dari penggunaan rubrik design kolaborasi, maka penulis melakukan penilaian kepada setiap kelompok. Sedangkan kuesioner ditujukan dalam penilaian diri siswa. Rubrik aspek kolaborasi menilai dinamika kelompok dari setiap kelompok. Dari data rubrik aspek kolaborasi, maka didapatkan data sebagai berikut:

\section{1) Collaboration Sesi I}

\section{DATA RUBRIK ASPEK KOLABORASI SESI I}

\begin{tabular}{|c|c|c|c|c|c|c|}
\hline NO & NAMA KELOMPOK & SUB ASPEK & SKOR & $\begin{array}{l}\text { KRITERIA } \\
\text { SKOR }\end{array}$ & $\begin{array}{l}\text { TOTAL } \\
\text { SKOR }\end{array}$ & $\%$ \\
\hline \multirow[t]{5}{*}{1} & HASANUDIN & $\begin{array}{l}\text { Productive } \mathcal{E} \\
\text { Efficient }\end{array}$ & 4 & BAIK SEKALI & 14 & 70 \\
\hline & & $\begin{array}{l}\text { Appreciation } \\
\text { Opinion }\end{array}$ & 3 & BAIK & & \\
\hline & & Contribution & 2 & KURANG & & \\
\hline & & $\begin{array}{l}\text { Compromise } \mathcal{E} \\
\text { Flexible }\end{array}$ & 2 & KURANG & & \\
\hline & & Responsibility & 3 & BAIK & & \\
\hline \multirow[t]{5}{*}{2} & IMAM BONJOL & $\begin{array}{l}\text { Productive } \mathcal{E} \\
\text { Efficient }\end{array}$ & 2 & KURANG & 16 & 80 \\
\hline & & $\begin{array}{l}\text { Appreciation } \\
\text { Opinion }\end{array}$ & 4 & BAIK SEKALI & & \\
\hline & & Contribution & 3 & BAIK & & \\
\hline & & $\begin{array}{l}\text { Compromise } \mathcal{E} \\
\text { Flexible }\end{array}$ & 3 & BAIK & & \\
\hline & & Responsibility & 4 & BAIK SEKALI & & \\
\hline \multirow[t]{5}{*}{3} & TEUKU UMAR & $\begin{array}{l}\text { Productive E } \\
\text { Efficient }\end{array}$ & 3 & BAIK & 17 & 85 \\
\hline & & $\begin{array}{l}\text { Appreciation } \\
\text { Opinion }\end{array}$ & 3 & BAIK & & \\
\hline & & Contribution & 4 & BAIK SEKALI & & \\
\hline & & $\begin{array}{l}\text { Compromise } \mathcal{E} \\
\text { Flexible }\end{array}$ & 3 & BAIK & & \\
\hline & & Responsibility & 4 & BAIK SEKALI & & \\
\hline \multirow[t]{5}{*}{4} & CUT NYAK DIEN & $\begin{array}{l}\text { Productive } \mathcal{E} \\
\text { Efficient }\end{array}$ & 4 & BAIK SEKALI & 18 & 90 \\
\hline & & $\begin{array}{l}\text { Appreciation } \\
\text { Opinion }\end{array}$ & 4 & BAIK SEKALI & & \\
\hline & & Contribution & 4 & BAIK SEKALI & & \\
\hline & & $\begin{array}{l}\text { Compromise } \mathcal{E} \\
\text { Flexible }\end{array}$ & 3 & BAIK & & \\
\hline & & Responsibility & 3 & BAIK & & \\
\hline \multirow[t]{2}{*}{5} & KARTINI & $\begin{array}{l}\text { Productive } \mathcal{E} \\
\text { Efficient }\end{array}$ & 3 & BAIK & 17 & 85 \\
\hline & & $\begin{array}{l}\text { Appreciation } \\
\text { Opinion }\end{array}$ & 4 & BAIK SEKALI & & \\
\hline
\end{tabular}




\begin{tabular}{|c|c|c|c|c|c|c|}
\hline \multirow{8}{*}{6} & \multirow{8}{*}{ PATTIMURA } & Contribution & 3 & BAIK & \multirow{8}{*}{15} & \multirow{8}{*}{75} \\
\hline & & Compromise $\mathcal{E}$ & 3 & BAIK & & \\
\hline & & $\begin{array}{l}\text { Flexible } \\
\text { Responsibility }\end{array}$ & 4 & BAIK SEKALI & & \\
\hline & & $\begin{array}{l}\text { Productive } \mathcal{E} \\
\text { Efficient }\end{array}$ & 3 & BAIK & & \\
\hline & & $\begin{array}{l}\text { Appreciation } \\
\text { Opinion }\end{array}$ & 3 & BAIK & & \\
\hline & & Contribution & 2 & KURANG & & \\
\hline & & $\begin{array}{l}\text { Compromise } \mathcal{E} \\
\text { Flexible }\end{array}$ & 3 & BAIK & & \\
\hline & & Responsibility & 4 & BAIK SEKALI & & \\
\hline
\end{tabular}

(Data Rubrik Aspek Collaboration terlampir)

Berdasarkan penilaian rubrik collaboration sesi I, maka didapatkan data pada setiap aspek yang mendapatkan kriteria skor BAIK SEKALI sejumlah 11 butir; untuk kriteria skor BAIK sejumlah 15 butir; dan untuk kriteria skor KURANG sejumlah 4 butir. Semakin banyak kriteria skor BAIK SEKALI yang diperoleh setiap kelompok, maka kelompok tersebut memiliki aspek collaboration yang baik pula.

\section{SEBARAN DATA RUBRIK COLLABORATION SESI I}

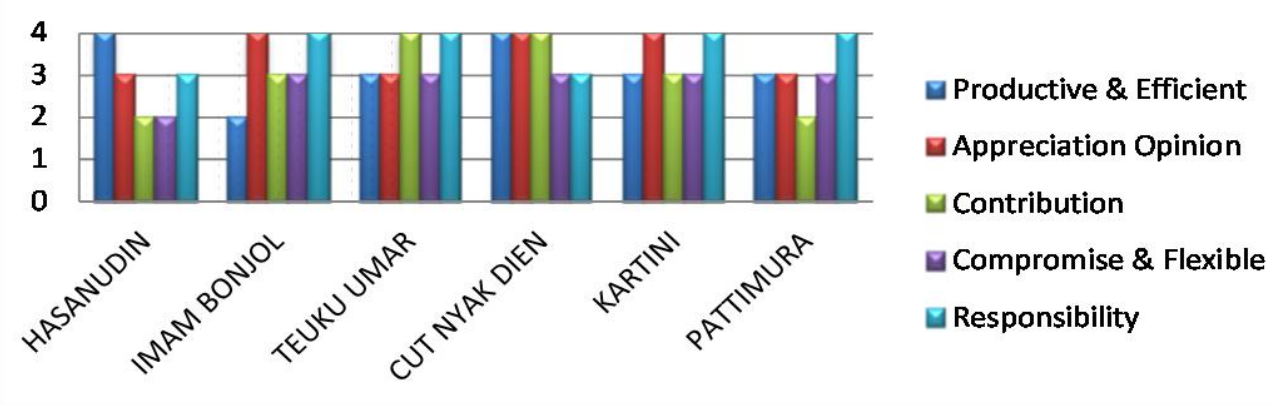

Untuk sebaran data pada setiap sub aspek, meliputi sub aspek Productive $\mathcal{E}$ Efficient memperoleh total nilai 19 dari total seluruh kelompok; sub aspek Appreciation Opinion memperoleh total nilai 21 dari total seluruh kelompok; sub aspek Contribution memperoleh total nilai 18 dari total seluruh kelompok; sub aspek Compromise \& Flexible memperoleh total nilai 17 dari total seluruh kelompok dan sub aspek Responsibility memperoleh total nilai 22 dari total seluruh kelompok. 
Selanjutnya untuk perolehan total skor pada setiap kelompok yaitu kelompok HASANUDIN mendapatkan total skor sejumlah 14; untuk kelompok IMAM BONJOL mendapatkan total skor sejumlah 16; untuk kelompok TEUKU UMAR mendapatkan total skor sejumlah 17; untuk kelompok CUT NYAK DIEN mendapatkan total skor sejumlah 18; untuk kelompok KARTINI mendapatkan total skor sejumlah 17 dan untuk kelompok PATTIMURA mendapatkan total skor sejumlah 15.

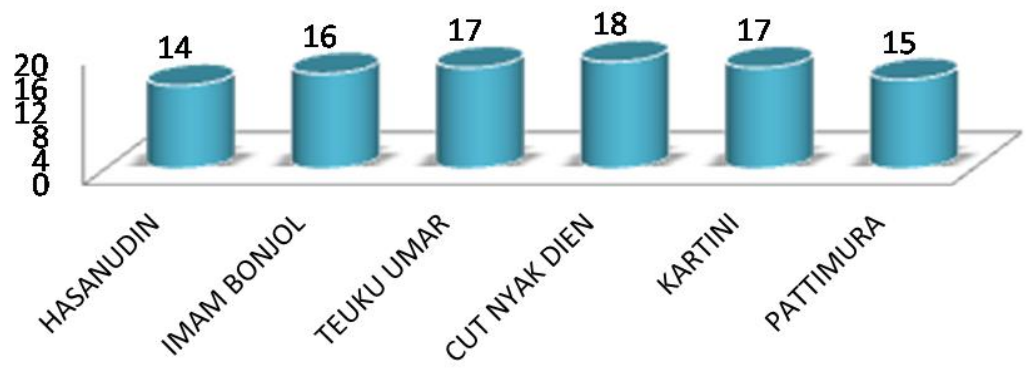

\section{2) Collaboration Sesi II}

\section{DATA RUBRIK ASPEK KOLABORASI SESI II}

\begin{tabular}{|c|c|c|c|c|c|}
\hline NO & NAMA KELOMPOK & SUB ASPEK & SKOR & $\begin{array}{l}\text { KRITERIA } \\
\text { SKOR }\end{array}$ & $\begin{array}{l}\text { TOTAL } \\
\text { SKOR }\end{array}$ \\
\hline \multirow[t]{5}{*}{1} & HASANUDIN & $\begin{array}{l}\text { Productive } \mathcal{E} \\
\text { Efficient }\end{array}$ & 3 & BAIK & 17 \\
\hline & & $\begin{array}{l}\text { Appreciation } \\
\text { Opinion }\end{array}$ & 3 & BAIK & \\
\hline & & Contribution & 4 & BAIK SEKALI & \\
\hline & & $\begin{array}{l}\text { Compromise } \mathcal{E} \\
\text { Flexible }\end{array}$ & 3 & BAIK & \\
\hline & & Responsibility & 4 & BAIK SEKALI & \\
\hline \multirow[t]{5}{*}{2} & IMAM BONJOL & $\begin{array}{l}\text { Productive } \mathcal{E} \\
\text { Efficient }\end{array}$ & 3 & BAIK & 18 \\
\hline & & $\begin{array}{l}\text { Appreciation } \\
\text { Opinion }\end{array}$ & 4 & BAIK SEKALI & \\
\hline & & Contribution & 3 & BAIK & \\
\hline & & $\begin{array}{l}\text { Compromise } \mathcal{E} \\
\text { Flexible }\end{array}$ & 4 & BAIK SEKALI & \\
\hline & & Responsibility & 4 & BAIK SEKALI & \\
\hline \multirow[t]{2}{*}{3} & TEUKU UMAR & $\begin{array}{l}\text { Productive } \mathcal{E} \\
\text { Efficient }\end{array}$ & 4 & BAIK SEKALI & 18 \\
\hline & & Appreciation & 3 & BAIK & \\
\hline
\end{tabular}




\begin{tabular}{|c|c|c|c|c|c|c|}
\hline & & \multicolumn{5}{|l|}{ Opinion } \\
\hline & & Contribution & 4 & BAIK SEKALI & & \\
\hline & & Compromise $\mathcal{E}$ & 3 & BAIK & & \\
\hline & & Flexible & & & & \\
\hline & & Responsibility & 4 & BAIK SEKALI & & \\
\hline \multirow[t]{5}{*}{4} & CUT NYAK DIEN & $\begin{array}{l}\text { Productive } \mathcal{E} \\
\text { Efficient }\end{array}$ & 4 & BAIK SEKALI & 19 & 95 \\
\hline & & Appreciation & 4 & BAIK SEKALI & & \\
\hline & & Contribution & 4 & BAIK SEKALI & & \\
\hline & & $\begin{array}{l}\text { Compromise } \mathcal{E} \\
\text { Flexible }\end{array}$ & 3 & BAIK & & \\
\hline & & Responsibility & 4 & BAIK SEKALI & & \\
\hline \multirow[t]{5}{*}{5} & KARTINI & $\begin{array}{l}\text { Productive } \mathcal{E} \\
\text { Efficient }\end{array}$ & 4 & BAIK SEKALI & 18 & 90 \\
\hline & & $\begin{array}{l}\text { Appreciation } \\
\text { Opinion }\end{array}$ & 4 & BAIK SEKALI & & \\
\hline & & Contribution & 4 & BAIK SEKALI & & \\
\hline & & $\begin{array}{l}\text { Compromise } \mathcal{E} \\
\text { Flexible }\end{array}$ & 3 & BAIK & & \\
\hline & & Responsibility & 3 & BAIK & & \\
\hline \multirow[t]{5}{*}{6} & PATTIMURA & $\begin{array}{l}\text { Productive } \mathcal{E} \\
\text { Efficient }\end{array}$ & 4 & BAIK SEKALI & 19 & 95 \\
\hline & & $\begin{array}{l}\text { Appreciation } \\
\text { Opinion }\end{array}$ & 4 & BAIK SEKALI & & \\
\hline & & Contribution & 3 & BAIK & & \\
\hline & & $\begin{array}{l}\text { Compromise } \mathcal{E} \\
\text { Flexible }\end{array}$ & 4 & BAIK SEKALI & & \\
\hline & & Responsibility & 4 & BAIK SEKALI & & \\
\hline
\end{tabular}

(Data Rubrik Aspek Collaboration terlampir)

Berdasarkan penilaian rubrik collaboration sesi II, maka didapatkan data pada setiap aspek yang mendapatkan kriteria skor BAIK SEKALI sejumlah 19 butir; untuk kriteria skor BAIK sejumlah 11 butir; dan untuk kriteria skor KURANG tidak ada. Semakin banyak kriteria skor BAIK SEKALI yang diperoleh setiap kelompok, maka kelompok tersebut memiliki aspek collaboration yang baik pula. 


\section{SEBARAN DATA RUBRIK COLLABORATION SESI II}

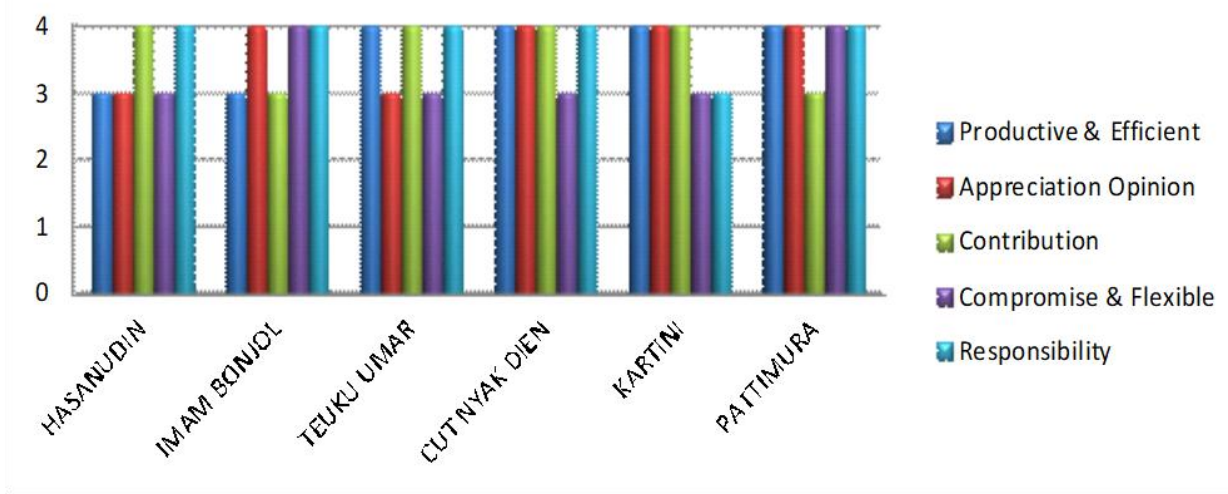

Untuk sebaran data pada setiap sub aspek, meliputi sub aspek Productive $\mathcal{E}$ Efficient memperoleh total nilai 22 dari total seluruh kelompok; sub aspek Appreciation Opinion memperoleh total nilai 22 dari total seluruh kelompok; sub aspek Contribution memperoleh total nilai 22 dari total seluruh kelompok; sub aspek Compromise $\mathcal{E}$ Flexible memperoleh total nilai 20 dari total seluruh kelompok dan sub aspek Responsibility memperoleh total nilai 23 dari total seluruh kelompok.

- TOTAL SKOR RUBRIK COLLABORATION SESI II

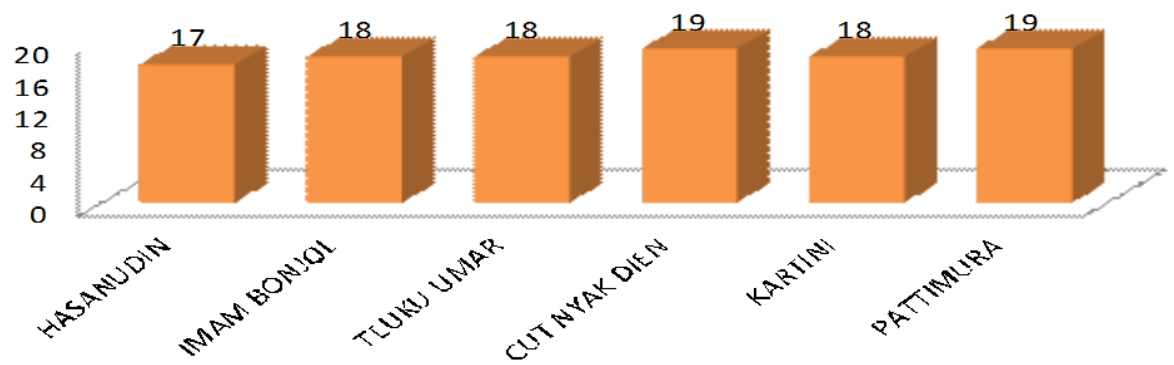

Selanjutnya untuk perolehan total skor pada setiap kelompok yaitu kelompok HASANUDIN mendapatkan total skor sejumlah 17; untuk kelompok IMAM BONJOL mendapatkan total skor sejumlah 18; untuk kelompok TEUKU UMAR mendapatkan total skor sejumlah 18; untuk kelompok CUT NYAK DIEN mendapatkan total skor sejumlah 19; 
untuk kelompok KARTINI mendapatkan total skor sejumlah 18 dan untuk kelompok PATTIMURA mendapatkan total skor sejumlah 19.

\section{b. Aspek Communication}

Desain rubrik aspek communication digambarkan pada Tabel 2.

Tabel2 Desain Rubrik Aspek Communication

\begin{tabular}{|c|c|c|c|c|c|c|}
\hline \multirow{2}{*}{ SUB ASPEK } & \multicolumn{4}{|c|}{ Deskripsi Skor } & \multirow{2}{*}{ Rentang Skor } & \multirow{2}{*}{ Kriteria Skor } \\
\hline & 1 & 2 & 3 & 4 & & \\
\hline Clarity & $\begin{array}{l}\text { Tidakmenggunakan } \\
\text { bahasa yangmudah } \\
\text { dipahami }\end{array}$ & $\begin{array}{l}\text { Mengounakan bahasa } \\
\text { yang tidakmudah } \\
\text { dipahami sebanyak } 2 \mathrm{kali}\end{array}$ & $\begin{array}{l}\text { Menggunakan bahasa } \\
\text { yang tidakmudah } \\
\text { dipahami sebanyak } 3-5 \\
\text { kali }\end{array}$ & $\begin{array}{l}\text { Selalu menggunakan } \\
\text { bahasa yangtidak } \\
\text { mudah dipahami }\end{array}$ & $1-4$ & $\begin{array}{l}\text { 1: KurangSekali } \\
2: \text { Kurang } \\
\text { 3:Baik } \\
\text { 4:BaikSekali }\end{array}$ \\
\hline Acauracy & $\begin{array}{l}\text { Mengounakan bahasa } \\
\text { yang benar, tapi } \\
\text { memberikan } 3 \text { kali } \\
\text { informasiyang kurang } \\
\text { benar }\end{array}$ & $\begin{array}{l}\text { Menggunakan bahasa } \\
\text { yang benar, tapi } \\
\text { memberikan } 2 \text { kali } \\
\text { informasi yang kurang } \\
\text { benar }\end{array}$ & $\begin{array}{l}\text { Menggunakan bahasa } \\
\text { yangbenar, tapi } \\
\text { memberikan } 1 \text { kali } \\
\text { informasiyang kurang } \\
\text { benar }\end{array}$ & $\begin{array}{l}\text { Selalu menggunakan } \\
\text { bahasa yang benar dan } \\
\text { informasi yang benar } \\
\text { pula }\end{array}$ & $1-4$ & $\begin{array}{l}\text { Kelompok akan } \\
\text { mendapatkankan nilai } \\
\text { sempuma bila memperoleh } \\
\text { NILAISEMPURNA yaitu } 20 \\
\text { (penjumlahandari setiap skor }\end{array}$ \\
\hline Context & $\begin{array}{l}\text { Pembahasan dan hasil } \\
\text { analisis dil luar konteks }\end{array}$ & $\begin{array}{l}\text { Hanya pembahasan yang } \\
\text { masuk pada materi, } \\
\text { sedangkan analisis di } \\
\text { luar konteks }\end{array}$ & $\begin{array}{l}\text { Pembahasansudah } \\
\text { sesuai materi, tapi } \\
\text { analisis kurang } \\
\text { mendalam }\end{array}$ & $\begin{array}{l}\text { Pembahasansudah } \\
\text { sesuaimateri, dan } \\
\text { analisis sudah } \\
\text { mendalam }\end{array}$ & $1-4$ & pada setiap sub aspek) \\
\hline Plot & $\begin{array}{l}\text { Hasil diskusi dananalisis } \\
\text { kelompok tidak tersusun } \\
\text { secara sistematis }\end{array}$ & $\begin{array}{l}\text { Hasil diskusi tersusun } \\
\text { secara sistematis, tetapi } \\
\text { hasil analisis kelompok } \\
\text { tidak tersusun sistematis }\end{array}$ & $\begin{array}{l}\text { Hasil diskusitidak } \\
\text { tersusun secara } \\
\text { sistematis, tetapihasil } \\
\text { analisis kelompok } \\
\text { tersusun sistematis }\end{array}$ & $\begin{array}{l}\text { Hasil diskusi dan } \\
\text { analisis kelompok } \\
\text { tersusun secara } \\
\text { sistematis }\end{array}$ & $1-4$ & \\
\hline Culture & $\begin{array}{l}\text { Tidakmemiliki etika } \\
\text { berdiskusi yang baik dan } \\
\text { tidakmenggunakan } \\
\text { bahasa verbal dan non } \\
\text { verbal }\end{array}$ & $\begin{array}{l}\text { Tidakmemilikietika } \\
\text { berdiskusi yang baik, } \\
\text { tapi sudah } \\
\text { menggunakan bahasa } \\
\text { verbal dan non verbal } \\
\text { yang baik }\end{array}$ & $\begin{array}{l}\text { Memiliki etika berdiskusi } \\
\text { yang baik, tapi tidak } \\
\text { mengounakan bahasa } \\
\text { verbal dan non verbal } \\
\text { yang baik }\end{array}$ & $\begin{array}{l}\text { Memilikietika } \\
\text { berdiskusi yang baik dan } \\
\text { pengounaan bahasa } \\
\text { verbal dan non verbal } \\
\text { yang baik pula }\end{array}$ & $1-4$ & \\
\hline
\end{tabular}

Dengan rubrik design komunikasi, maka penulis melakukan penilaian kepada setiap kelompok. Sedangkan kuesioner ditujukan dalam penilaian diri siswa. Rubrik aspek komunikasi menilai dinamika kelompok dari setiap kelompok. Dari data rubrik aspek komunikasi, maka didapatkan data sebagai berikut:

\section{1) Communication Sesi I}

\section{DATA RUBRIK ASPEK COMMUNICATION SESI I}

\begin{tabular}{|c|c|c|c|c|c|c|}
\hline NO & NAMA KELOMPOK & SUB ASPEK & SKOR & $\begin{array}{l}\text { KRITERIA } \\
\text { SKOR }\end{array}$ & $\begin{array}{l}\text { TOTAL } \\
\text { SKOR }\end{array}$ & $\%$ \\
\hline \multirow[t]{5}{*}{1} & HASANUDIN & Clarity & 3 & BAIK & 16 & 80 \\
\hline & & Accuracy & 3 & BAIK & & \\
\hline & & Context & 3 & BAIK & & \\
\hline & & Plot & 3 & BAIK & & \\
\hline & & Culture & 4 & BAIK SEKALI & & \\
\hline \multirow[t]{2}{*}{2} & IMAM BONJOL & Clarity & 3 & BAIK & 15 & 75 \\
\hline & & Accuracy & 3 & BAIK & & \\
\hline
\end{tabular}




\begin{tabular}{|c|c|c|c|c|c|c|}
\hline \multirow[t]{4}{*}{ NO } & NAMA KELOMPOK & SUB ASPEK & SKOR & $\begin{array}{l}\text { KRITERIA } \\
\text { SKOR }\end{array}$ & $\begin{array}{l}\text { TOTAL } \\
\text { SKOR }\end{array}$ & $\%$ \\
\hline & & Context & 3 & BAIK & & \\
\hline & & Plot & 2 & KURANG & & \\
\hline & & Culture & 4 & BAIK SEKALI & & \\
\hline \multirow[t]{5}{*}{3} & TEUKU UMAR & Clarity & 3 & BAIK & 16 & 80 \\
\hline & & Accuracy & 4 & BAIK SEKALI & & \\
\hline & & Context & 3 & BAIK & & \\
\hline & & Plot & 3 & BAIK & & \\
\hline & & Culture & 3 & BAIK & & \\
\hline \multirow[t]{5}{*}{4} & CUT NYAK DIEN & Clarity & 4 & BAIK SEKALI & 17 & 85 \\
\hline & & Accuracy & 3 & BAIK & & \\
\hline & & Context & 3 & BAIK & & \\
\hline & & Plot & 4 & BAIK SEKALI & & \\
\hline & & Culture & 3 & BAIK & & \\
\hline \multirow[t]{5}{*}{5} & KARTINI & Clarity & 3 & BAIK & 17 & 85 \\
\hline & & Accuracy & 3 & BAIK & & \\
\hline & & Context & 4 & BAIK SEKALI & & \\
\hline & & Plot & 4 & BAIK SEKALI & & \\
\hline & & Culture & 3 & BAIK & & \\
\hline \multirow[t]{5}{*}{6} & PATTIMURA & Clarity & 3 & BAIK & 15 & 75 \\
\hline & & Accuracy & 2 & KURANG & & \\
\hline & & Context & 3 & BAIK & & \\
\hline & & Plot & 3 & BAIK & & \\
\hline & & Culture & 4 & BAIK SEKALI & & \\
\hline
\end{tabular}

(Data Rubrik Aspek Communication terlampir)

Berdasarkanpenilaian rubrik communicatiom sesi I, maka didapatkan data pada setiap aspek yang mendapatkan kriteria skor BAIK SEKALI sejumlah 8 butir; untuk kriteria skor BAIK sejumlah 20 butir; dan untuk kriteria skor KURANG sejumlah 2 butir. Semakin banyak kriteria skor BAIK SEKALI yang diperoleh setiap kelompok, maka kelompok tersebut memiliki aspek communication yang baik pula.

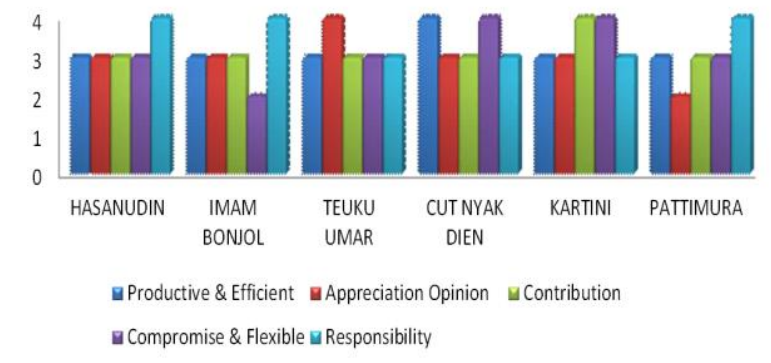


Untuk sebaran data pada setiap sub aspek, meliputi sub aspek Claritymemperolehtotal nilai 19 dari total seluruh kelompok; sub aspek Accuracy memperoleh total nilai 18 dari total seluruh kelompok; sub aspek Context memperoleh total nilai 19 dari total seluruh kelompok; sub aspek

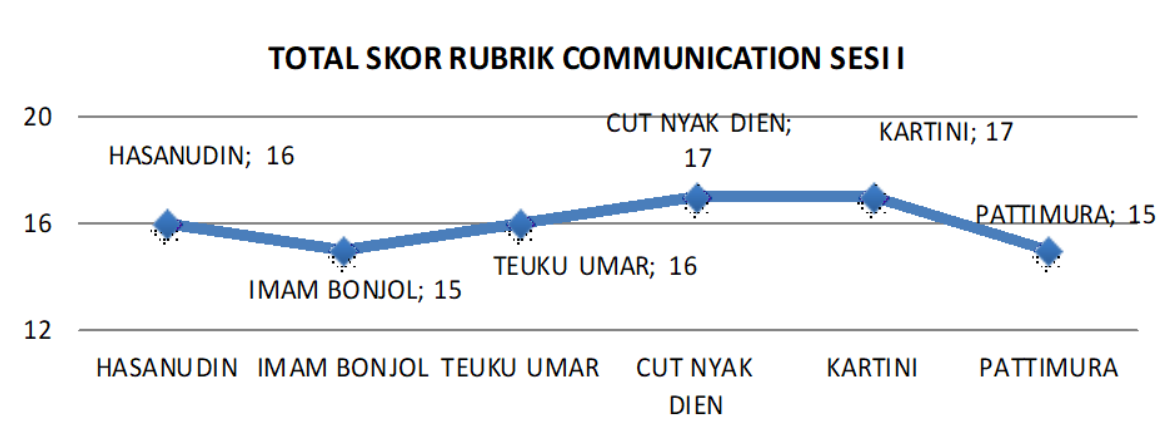

Plot memperoleh total nilai 19 dari total seluruh kelompok dan sub aspek Culture memperoleh total nilai 21 dari total seluruh kelompok.Selanjutnya untuk perolehan total skor pada setiap kelompok yaitu kelompok HASANUDIN mendapatkantotal skor sejumlah 16; untuk kelompok IMAM BONJOL mendapatkan total skor sejumlah 15; untuk kelompok TEUKU UMAR mendapatkan total skor sejumlah 16; untuk kelompok CUT NYAK DIEN mendapatkan total skor sejumlah 17; untuk kelompok KARTINI mendapatkan total skor sejumlah 17 dan untuk kelompok PATTIMURA mendapatkan total skor sejumlah 15.

\section{2) Communication Sesi II}

DATA RUBRIK ASPEK COMMUNICATION SESI II

\begin{tabular}{|c|c|c|c|c|c|c|}
\hline NO & $\begin{array}{c}\text { NAMA } \\
\text { KELOMPOK }\end{array}$ & $\begin{array}{l}\text { SUB } \\
\text { ASPEK }\end{array}$ & SKOR & $\begin{array}{c}\text { KRITERIA } \\
\text { SKOR }\end{array}$ & $\begin{array}{l}\text { TOTAL } \\
\text { SKOR }\end{array}$ & $\%$ \\
\hline \multirow[t]{5}{*}{1} & HASANUDIN & Clarity & 4 & BAIK SEKALI & 18 & 90 \\
\hline & & Accuracy & 3 & BAIK & & \\
\hline & & Context & 3 & BAIK & & \\
\hline & & Plot & 4 & BAIK SEKALI & & \\
\hline & & Culture & 4 & BAIK SEKALI & & \\
\hline \multirow[t]{5}{*}{2} & IMAM BONJOL & Clarity & 4 & BAIK SEKALI & 16 & 80 \\
\hline & & Accuracy & 3 & BAIK & & \\
\hline & & Context & 3 & BAIK & & \\
\hline & & Plot & 2 & KURANG & & \\
\hline & & Culture & 4 & BAIK SEKALI & & \\
\hline 3 & TEUKU UMAR & Clarity & 3 & BAIK & 17 & 85 \\
\hline
\end{tabular}




\begin{tabular}{|c|c|c|c|c|c|c|}
\hline & & Accuracy & 4 & BAIK SEKALI & & \\
\hline & & Context & 3 & BAIK & & \\
\hline & & Plot & 4 & BAIK SEKALI & & \\
\hline & & Culture & 3 & BAIK & & \\
\hline \multirow[t]{5}{*}{4} & CUT NYAK & Clarity & 4 & BAIK SEKALI & 19 & 95 \\
\hline & DIEN & Accuracy & 3 & BAIK & & \\
\hline & & Context & 4 & BAIK SEKALI & & \\
\hline & & Plot & 4 & BAIK SEKALI & & \\
\hline & & Culture & 4 & BAIK SEKALI & & \\
\hline \multirow[t]{5}{*}{5} & KARTINI & Clarity & 4 & BAIK SEKALI & 19 & 95 \\
\hline & & Accuracy & 3 & BAIK & & \\
\hline & & Context & 4 & BAIK SEKALI & & \\
\hline & & Plot & 4 & BAIK SEKALI & & \\
\hline & & Culture & 4 & BAIK SEKALI & & \\
\hline \multirow[t]{5}{*}{6} & PATTIMURA & Clarity & 3 & BAIK & 17 & 85 \\
\hline & & Accuracy & 3 & BAIK & & \\
\hline & & Context & 3 & BAIK & & \\
\hline & & Plot & 4 & BAIK SEKALI & & \\
\hline & & Culture & 4 & BAIK SEKALI & & \\
\hline
\end{tabular}

(Data Rubrik Aspek Communicationterlampir)

Berdasarkan penilaian rubrik communicatiom, maka didapatkan data pada setiap aspek yang mendapatkan kriteria skor BAIK SEKALI sejumlah 17 butir; untuk kriteria skor BAIK sejumlah 12 butir; dan untuk kriteria skor KURANG sejumlah 1 butir. Semakin banyak kriteria skor BAIK SEKALI yang diperoleh setiap kelompok, maka kelompok tersebut memiliki aspek communication yang baik pula.

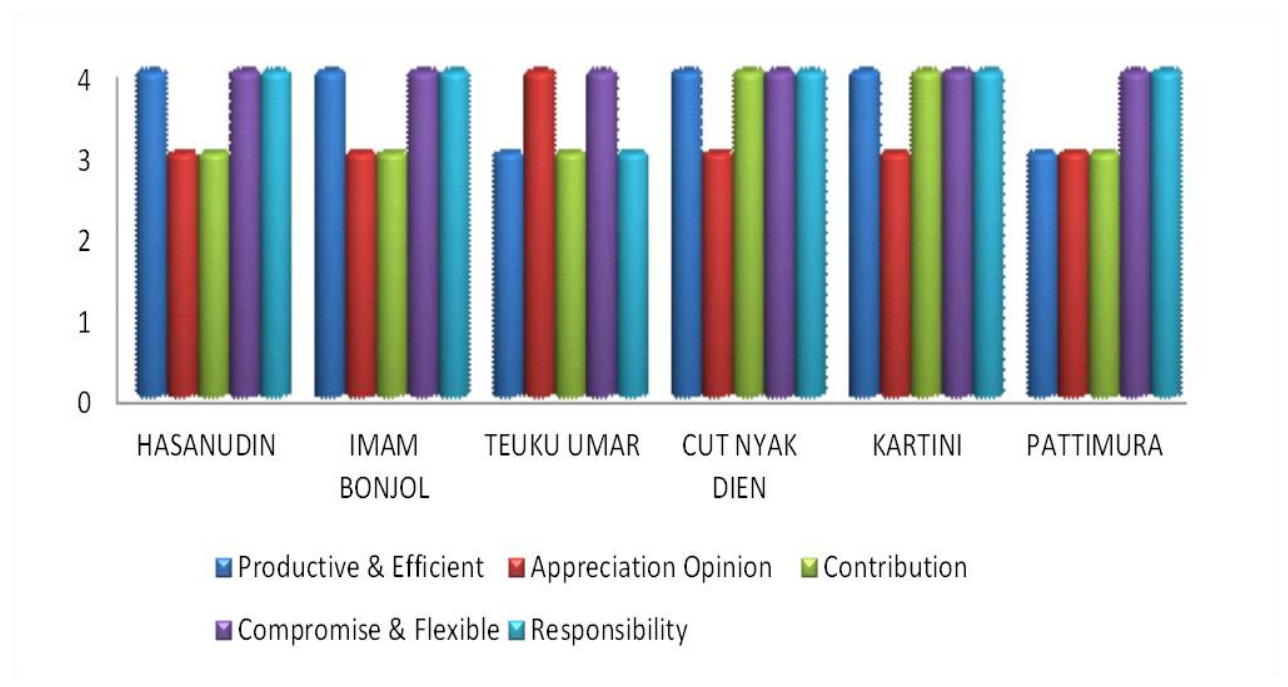


Untuk sebaran data pada setiap sub aspek, meliputi sub aspek Clarity memperoleh total nilai 22 dari total seluruh kelompok; sub aspek Accuracy memperoleh total nilai 19 dari total seluruh kelompok; sub aspek Context memperoleh total nilai 20 dari total seluruh kelompok; sub aspek Plot memperoleh total nilai 22 dari total seluruh kelompok dan sub aspek Culture memperoleh total nilai 23 dari total seluruh kelompok.

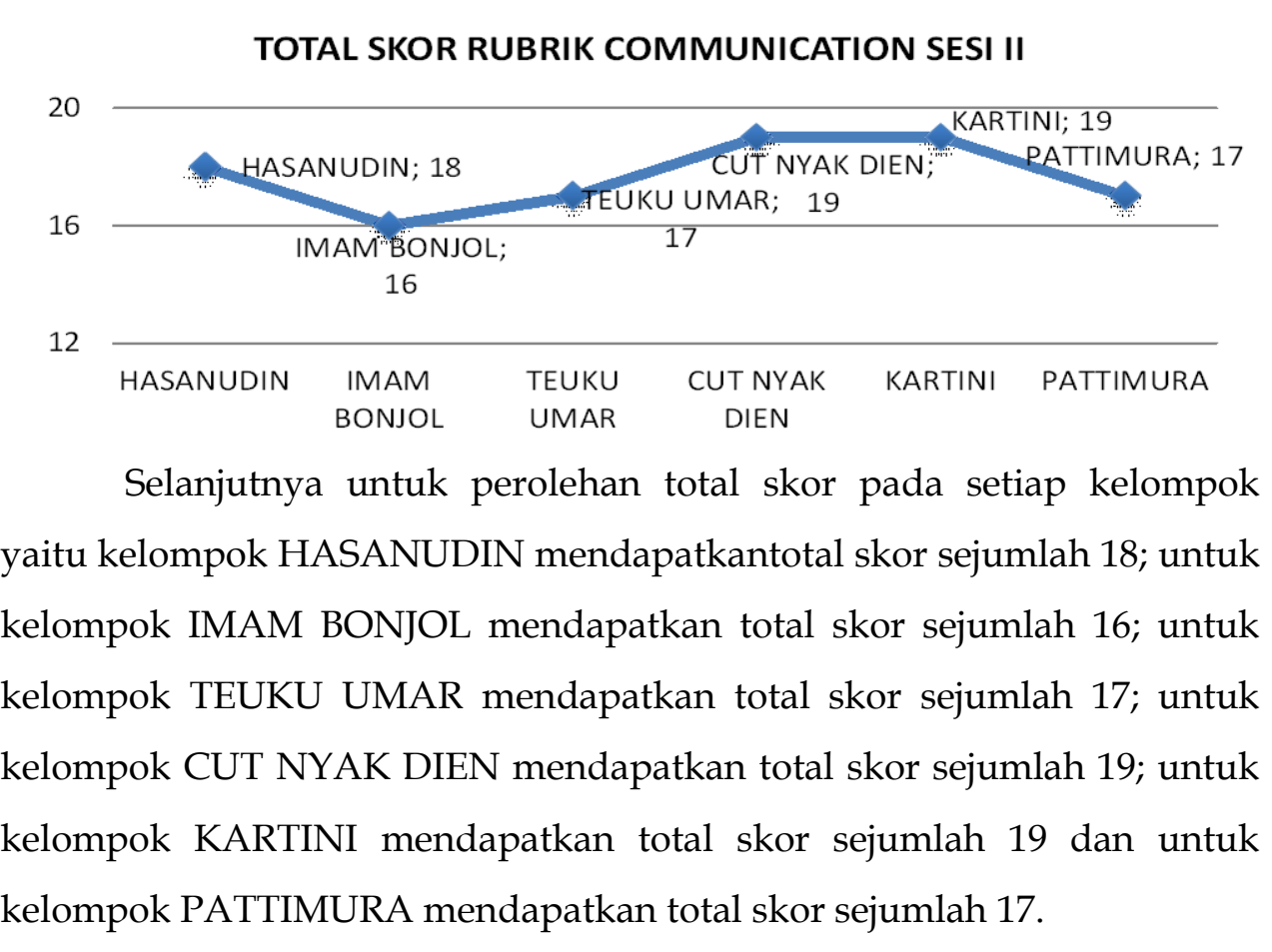

\section{c. Aspek Kognitif}

Penilaian menggunakan tes tulis dan uraian. Tes tulis dan uraian ditujukan untuk melihat progres pengetahuan siswa secara individu dalam memahami materi yang sudah dipelajari. Adapun tes tulis dan uraian berupa ulangan harian I, II dan III. Adapun hasil rekapitulasi hasil ulangan siswa sebagai berikut.

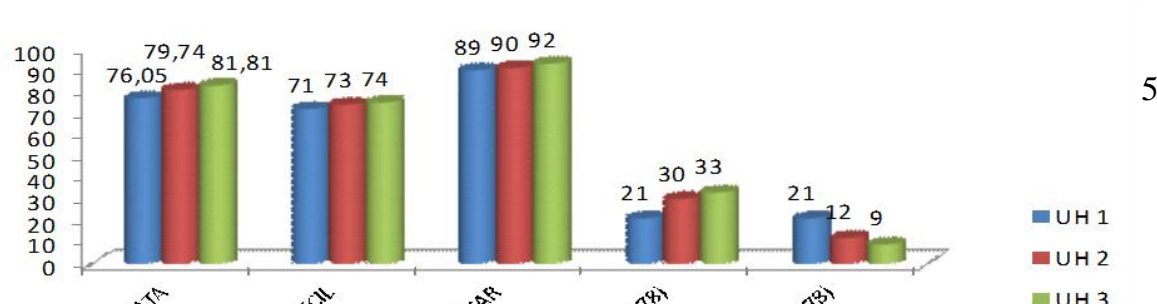


Siswa kelas IX-D memperoleh nilai rata (Average) yang mengalami kenaikan untuk Ulangan Harian I sampai III, begitu pun Nilai Terkecil (Min) dan Nilai Terbesar (Max) serta jumlah siswa yang mencapai atau tidak terhadap KetuntasanBelajar Minimal (78) mengalami kenaikan untuk setiap Ulangan Harian I sampai III.Tahapan analisis data adalah proses menganalisis lebih mendalam mengenai aspek Collaboration, Communication dan Kognitif yang telah didapat oleh penulis dalam melakukan penilaian dalam bentuk rubrik maupun pemberian tes uraian kepada siswa. Dalam analisis data ini, penulis akan menjabarkan mengenai progres penggunaan metode CSS dalam pelajaran IPS.

\section{Analisis Data Hasil Aplikasi Metode CSS dalam Pembelajaran}

Tahapan analisis data adalah proses menganalisis lebih mendalam mengenai aspek Collaboration, Communication dan Kognitif yang telah didapat oleh penulis dalam melakukan penilaian dalam bentuk rubrik maupun pemberian tes uraian kepada siswa. Dalam analisis data ini, penulis akan menjabarkan mengenai progres penggunaan metode CSS dalam pelajaran IPS.

\section{a. Aspek Collaboration}

Berdasarkan data mengenai aspek Collaborationsesi I dan II, dapat dianalisis adanya peningkatan dalam aspek kolaborasi siswa dengan menggunakan metode CSS. Adapun data yang direkap, sebagai berikut.

PERBANDINGAN PENILAIAN ASPEK COLLABORATION SESI I DAN II

\begin{tabular}{clccccc} 
NO & $\begin{array}{c}\text { NAMA } \\
\text { KELOMPOK }\end{array}$ & \multicolumn{2}{c}{ TOTAL SKOR } & \multicolumn{2}{c}{ PERSENTASE (\%) } & KENAIKAN \\
& SESI I & SESI II & SESI I & SESI II & $\begin{array}{c}\text { PERSTASE } \\
(\%)\end{array}$ \\
\hline 1 & HASANUDIN & 14 & 17 & 70 & 85 & 15 \\
2 & IMAM BONOL & 16 & 18 & 80 & 90 & 10 \\
3 & TEUKU UMAR & 17 & 18 & 85 & 90 & 5 \\
4 & CUT NYAK DIEN & 17 & 19 & 85 & 95 & 10
\end{tabular}


Lestari Kurniawati

$\begin{array}{llllllc}5 & \text { KARTINI } & 17 & 18 & 85 & 90 & 5 \\ 6 & \text { PATIMURA } & 15 & 19 & 75 & 95 & 20\end{array}$

Berdasarkan hasil perbandingan penilaian aspek Collaboration sesi I dan II, didapatkan kenaikan persentase pada aspek collaboration yaitu: 1).KelompokHasanudin sejumlah $15 \%$ yang dilihat dari kenaikan persentase sesi I (70\%) meningkat pada sesi II (85\%); 2). KelompokImam Bonjol sejumlah 10\% yang dilihat dari kenaikan persentase sesi I (80\%) meningkat pada sesi II (90\%); 3). KelompokTeuku Umar sejumlah 5\% yang dilihat dari kenaikan persentase sesi I (85\%) meningkat pada sesi II (90\%); 4). KelompokCut Nyak Dien sejumlah $10 \%$ yang dilihat dari kenaikan persentase sesi I (85\%) meningkat pada sesi II (95\%); 5). KelompokKartini sejumlah 5\% yang dilihat dari kenaikan persentase sesi I (85\%) meningkat pada sesi II (90\%); dan 6). KelompokPattimura sejumlah $20 \%$ yang dilihat dari kenaikan persentase sesi I (75\%) meningkat pada sesi II (95\%).

\section{b. Aspek Communication}

Berdasarkan data mengenai aspek Communicationsesi I dan II, dapat dianalisis adanya peningkatan dalam aspek komunikasi siswa dengan menggunakan metode CSS. Adapun data yang direkap, sebagai berikut:

PERBANDINGAN PENILAIAN ASPEK COMMUNICATION SESI I DAN II

\begin{tabular}{|c|c|c|c|c|c|c|}
\hline \multirow[b]{2}{*}{ NO } & \multirow{2}{*}{$\begin{array}{c}\text { NAMA } \\
\text { KELOMPOK }\end{array}$} & \multicolumn{2}{|c|}{ TOTAL SKOR } & \multicolumn{2}{|c|}{ PERSENTASE (\%) } & \multirow{2}{*}{$\begin{array}{c}\text { KENAIKAN } \\
\text { PERSENTASE } \\
(\%)\end{array}$} \\
\hline & & SESI I & SESI II & SESI I & SESI II & \\
\hline 1 & HASANUDIN & 16 & 18 & 80 & 90 & 10 \\
\hline 2 & IMAM BONOL & 15 & 16 & 75 & 80 & 5 \\
\hline 3 & TEUKU UMAR & 16 & 17 & 80 & 85 & 5 \\
\hline 4 & CUT NYAK DIEN & 17 & 19 & 85 & 95 & 10 \\
\hline 5 & KARTINI & 17 & 19 & 85 & 95 & 10 \\
\hline 6 & PATTIMURA & 15 & 17 & 75 & 85 & 10 \\
\hline
\end{tabular}

Berdasarkan hasil perbandingan penilaian aspek Communication sesi I dan II, didapatkan kenaikan persentase pada aspek 
Communicationyaitu: 1). Kelompok Hasanudin sejumlah 10\% yang dilihat dari kenaikan persentase sesi I (80\%) meningkat pada sesi II (90\%); 2). Kelompok Imam Bonjol sejumlah 5\% yang dilihat dari kenaikan persentase sesi I (75\%) meningkat pada sesi II (80\%); 3). Kelompok Teuku Umar sejumlah $5 \%$ yang dilihat dari kenaikan persentase sesi I (80\%) meningkat pada sesi II (85\%); 4). Kelompok Cut Nyak Dien sejumlah 10\% yang dilihat dari kenaikan persentase sesi I (85\%) meningkat pada sesi II (95\%); 5). Kelompok Kartini sejumlah 10\% yang dilihat dari kenaikan persentase sesi I (85\%) meningkat pada sesi II (95\%); dan 6). Kelompok Pattimura sejumlah $10 \%$ yang dilihat dari kenaikan persentase sesi I (75\%) meningkat pada sesi II (85\%).

\section{c. Aspek Kognitif}

Berdasarkan rekap data penilaian kognitif untuk Ulangan Harian I, II dan III, maka terjadi peningkatan pengetahuan siswa dalam hal: 1). Nilai Rata-rata/Average pada setiap Ulangan Harian I (76,05); Ulangan Harian II $(79,74)$; dan Ulangan Harian III $(81,81)$. Untuk siswa yang memperoleh Nilai Terkecil/MIN pada setiap Ulangan Harian juga mengalami peningkatan, pada Ulangan Harian I (71); Ulangan Harian II (73); dan Ulangan Harian III (74). Ulangan Harian II $(79,74)$; dan Ulangan Harian III $(81,81)$. Untuk siswa yang memperoleh Nilai Terbesar/MAX pada setiap Ulangan Harian juga mengalami peningkatan, pada Ulangan Harian (89); Ulangan Harian II (90); dan Ulangan Harian III (92). Selanjutnya, untuk jumlah siswa yang dinyatakan lulus dan sesuai dengan KBM (78) mengalami peningkatan pada Ulangan Harian I jumlah siswa yang lulus (21 siswa); Ulangan Harian II (30 siswa); dan Ulangan Harian III (33 siswa). Kategori penilaian dilihat dari jumlah siswa yang tidak lulus/dibawah KBM (78) mengalami penurunan pada Ulangan Harian I jumlah siswa yang tidak lulus (21 siswa); Ulangan Harian II (12 siswa); dan Ulangan Harian III (9 siswa). Selanjutnya, kategori penilaian terakhir berdasarkan persentase kelulusan siswa (sesuai dan atau diatas 
KBM), untuk Ulangan Harian I (50\%), Ulangan Harian II $(71,4 \%)$ dan Ulangan Harian III (78,5\%).

\section{Penutup}

Berdasarkan hasil implementasi karya inovasi metode Consultant Social Science (CSS), maka didapatkan simpulan penelitian:

1. Metode Consultant Social Science (CSS) dapat meningkatkan aspek Collaboration siswa. Berdasarkan hasil perbandingan penilaian aspek Collaboration sesi I dan II, didapatkan kenaikan persentase pada aspek collaboration yaitu: 1). Kelompok Hasanudin sejumlah 15\%; 2). KelompokImam Bonjol sejumlah 10\%; 3). KelompokTeuku Umar sejumlah 5\%; 4). Kelompok Cut Nyak Dien sejumlah 10\%; 5). Kelompok Kartini sejumlah 5\% dan KelompokPattimura sejumlah 20\%.

2. Metode Consultant Social Science (CSS) dapat meningkatkan aspek Communication siswa. Berdasarkan hasil perbandingan penilaian aspek Communication sesi I dan II, didapatkan kenaikan persentase pada aspek Communication yaitu: 1). Kelompok Hasanudin sejumlah 10\%; 2). Kelompok Imam Bonjol sejumlah 5\%; 3). Kelompok Teuku Umar sejumlah 5\%; 4). Kelompok Cut Nyak Dien sejumlah 10\%; 5). Kelompok Kartini sejumlah 10\%; dan 6). Kelompok Pattimura sejumlah 10\%.

\section{Ucapan Terimakasih}

Terima kasih kepada Kepala Sekolah SMPN 1 Rangkasbitung, Bapak H. Sudirman, M.Si dan rekan-rekan guru SMPN 1 Rangkasbitung atas dukungan moral sehingga terselesaikannya penelitian ini. Terima kasih juga kepada kolaborator penelitian yakni Ibu Tita Tresnawati, M.Pd, kepada siswa-siswi, khususnya kelas IX-D, atas kerjasama dan dinamika pembelajaran yang menarik.

\section{Daftar Referensi}

Anantyarta, P., \& Sari, R. L. (2017). Keterampilan Kolaboratif dan Metakognitif melalui Media Berbasis Means Ends Analysis Collaborative and Metakognitive Skills Through Multimedia 
Means Ends and Analysis Based. Jurnal Biologi dan Pembelajaran Biologi, 37.

Freire, P. (2011). Pendidikan Kaum Tertindas (Alih bahasa: Tim Redaksi LP3ES). Jakarta: Pustaka LP3ES Indonesia.

Kamber,D. (2000). Action Learning Research Improving The Quality of Teaching And Learning. London: Page Limited

Khasali, R. (2018). Distruption (Tak ada yang tak bisa Diubah Sebelum Dihadapi, Motivasi saja tidak cukup). Jakarta: PT. Gramedia Pustaka Utama.

Lasidos, Pahala Arion dan Zulkifli Matondang. (2015). Penerapan Model Pembelajaran Kolaboratif Untuk Meningkatkan Aktivitas Dan Hasil Belajar Rencana Anggaran Biaya Siswa Kelas XII Kompetensi Keahlian Teknik Gambar Bangunan Smkn 2 Siatas Barita Tapanuli Utara. Jurnal Educational Building, 13 - 22.

Lestari. G, E. d. (2015). Komunikasi yang Efektif. Jakarta: Lembaga Administrasi Negara.

Santrock, J. W. (2010). Psikologi Pendidikan, Edisi Kedua. Kencana Prenada Media Grup: Jakarta.

Silberman, B. d. (2010). Active Learning (101 Strategi Pembelajaran Aktif). Jogjakarta: Pustaka Insan Madani.

Uno, B. H., \& Mohamad, N. (2011). Belajar dengan Pendekatan PAILKEM: Pembelajaran Aktif, Inovatif, Lingkungan, Kratif, Efektif, Menarik. Jakarta: PT Bumi Aksara.

Siswanto, R., Sugiono, S., \& Prasojo, L. (2018). The Development of Management Model Program of Vocational School Teacher Partnership with Business World and Industry Word (DUDI). Jurnal Ilmiah Peuradeun, 6(3), 365-384. doi:10.26811/peuradeun.v6i3.322

Lewis, M., \& Ponzio, V. (2016). Character Education as the Primary Purpose of Schooling for the Future. Jurnal Ilmiah Peuradeun, 4(2), 137-146. doi:10.26811/ peuradeun.v4i2.92

Auratu. (2018, April 2). Perubahan Sikap Siswa Pasif ketika Menggunakan CSS. (L. Kurniawati, Pewawancara) 
